Katarina Jevtić-Novaković
Ph.D., Professor of Applied Studies, College of Civil Engineering and Geodesy,

Belgrade Serbia

\title{
Descriptive Geometry in Serbia at the end of the 19th Century, in the Work of Dimitrije Stojanović
}

\author{
Olga Timčenko \\ Ph.D., Associate Professor, \\ Design and Media Technology, \\ Aalborg University, \\ Copenhagen \\ Denmark \\ Marija Divac \\ Assistant, PhD student \\ Belgrade \\ Serbia
} College of Civil Engineering and Geodesy,

\begin{abstract}
In this paper we will look at the early history of teaching descriptive geometry in Serbia, concentrating on Dimitrije Stojanovic's "Methodology of Descriptive Geometry". This book was 25 years in the making, he started writing it in 1874, completed and published it in 1899. So comprehensive was this textbook that though it was written in the last quarter of $19^{\text {th }}$ century it exceedes many modern textbooks in its scope. It has 692 pages of the text and 462 drawings, which were separately printed at the end of the book. Stojanovic's "Methodology of Descriptive Geometry" is the first attempt to synthesize descriptive and projective geometry.
\end{abstract}

Keywords: Dimitrije Stojanovic, descriptive geometry, projective geometry, synthesis, Serbia

\section{INTRODUCTION}

The development of higher education in Serbia began in the 19th century. It is related to the creation of a modern Serbian state, after liberation from centuries old Turkish rule. The development of the education system and its modernization was accompanied by numerous obstacles, mostly lack of funds, as well as by conflicts and disagreements over different ideas about the creation of school institutions. Those conflicts and disagreements slowed down the rapid development of education in Serbia. (and are still with us today - it's a rare occasion to have a full agreement over anything in Serbia). According to some authors [1] it all begins with Higher School, founded in 1808., where Law was studied in courses of 3 years duration. The School was abolished during the breakdown of the First Serbian Uprising in 1813. However, development of higher education in Serbia continued with foundation of the Lyceum, in Kragujevac in 1838. The Lyceum was later moved to Belgrade, in 1841. The choice of subjects being studied was indicative of the need for higher educated people primarily in the state administration. The natural sciences were given more importance by establishing the Natural-technical department with the reform in 1853, with teaching staff coming mainly from Austria, mostly Serbs but also Germans and Czechs. The establishment of the Artillery school in 1850 was also a very important factor in the development of Geometry studies in Serbia. The Artillery school was a forerunner of the Military Academy, where mathematics and technical disciplines were studied at significantly higher level than in Lyceum. The great reform of Lyceum was carried out in 1863, during the reign of Prince Mihailo Obrenovic, when the Higher School was founded,

Received: June 2018, Accepted: December 2018

Correspondence to: Katarina Jevtić-Novaković, Professor of Applied Studies, College of Civil Engineering and Geodesy, Belgrade, Serbia E-mail: katarina.jn@gmail.com

doi:10.5937/fmet1902267J

(C) Faculty of Mechanical Engineering, Belgrade. All rights reserved which would grow into the University in the beginning of 20th century, in 1905. The existing departments developed into faculties of the Higher School: Philosophical, Law and Technical.

With regard to studying Geometry in Serbia, in Lyceum it was studied as a separate subject, with a modest curriculum, as it can be seen from the textbook "Elementary Geometry" from 1841 by Atanasije Nikolic. Amongst the notable professors of the Higher School, since its foundation, is Emilijan Josimovic, who studied at Vienna Polytechnics School. After becoming a professor of Lyceum in 1845 and a professor of the Artillery school in 1854, he finally became a professor of Higher School in 1869. He taught mathematics, practical geometry (geodesy), civil architecture and descriptive geometry. He wrote several textbooks, among which are "Principles of Higher Mathematics" $(1858,1872)$ and the "Basics of Descriptive Geometry and Perspective" (1874). He is the author of the first urban plan of Belgrade (1867). History will remember him as the first Serbian urbanist. Students of Philosophy and Technical department of the Higher school were being taught descriptive geometry since 1880. Dimitrije Stojanovic and Milan Kapetanovic were the professors during that period.

\section{BIOGRAPHY OF DIMITRIJE STOJANOVIC}

Biographical data about Dimitrije Stojanovic are very scarce. We gained some knowledge from the Serbian encyclopedia website, the largest part from the obituary, written by the mathematician Bogdan Gavrilovic. We also have some modest data coming from Milan Bozic, a professor at the Faculty of Mathematics, in his work "The Review of History of Mathematics in Serbia".

His resume, in short, is as follows. Dimitrije Stojanovic was born on October 27, 1841 and died on September 15, 1905. He started his education in his native Pozarevac, continued it in Belgrade and Vienna, where he finished Polytechnics. Upon completing his studies, he returned to his homeland and entered the 
civil service. He got employed in 1867 as a district engineer in Pozarevac. His engineering career certainly went uphill and we can freely say that, if not more significant, it was certainly more exciting than his teaching career. In a few words, we will highlight his most important engineering work. In 1880 he became the director and founder of the Railway Department at the Ministry of Construction. During 1884, the Government, supported by King Milan, and without consulting Stojanovic, authorized the Railway company of Serbia, governed by foreigners, to negotiate the tariffs with international railways. In order to prevent great damages to the state, Stojanovic threatened the director of the Company to forego this right of negotiations or he would inflict great damages to the Company as inspector [2]. After that, the company gave over the right to the state. Stojanovic protected the state many times, refusing to accept many badly constructed railroad facilities. When the Serbian Railways Directorate was established for the exploitation of railways in Serbia under state administration, he was appointed the first director of the Serbian State Railways and he performed this duty for a long time. He was the minister of construction and consultant in the government several times. He was also finance minister in the government of Jovan Avakumovic in 1892. In late 1898 and early 1899 , he was sent to Vienna to negotiate a state-owned railway exploitation loan. After successfully completing this task, he became the Minister of Construction in the Government of Vladan Djordjevic in 1899.

So Dimitrije Stojanovic was certainly the first (and probably the last) professor of descriptive geometry who was also a minister in Serbia.

As a professor of descriptive geometry at Higher School, he began his professorial career in 1874, and then at the Artillery School (the forerunner of the Military Academy) between 1878 and 1880 [3]. He participated in the founding of the Technical Society in 1868 (the forerunner of the Association of Engineers and Technicians), whose president was Emilijan Josimovic, and, still being young engineer, he was elected for a scribe.

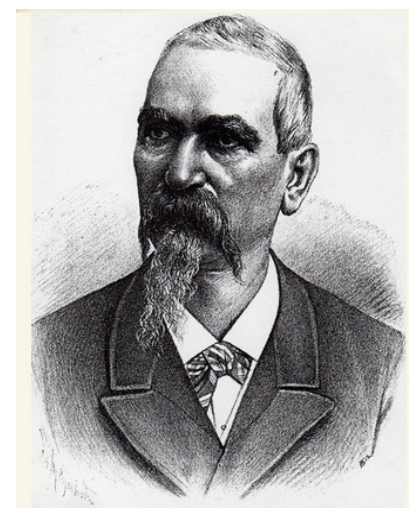

Figure 1. Dimitrije Stojanovic

For the merits acquired during the construction and exploitation of the first Serbian state railway, by the decree of King Milan, in 1888, he was awarded the Takovo Cross. He also worked on Slavic philology. He wrote several discussions in the "Glasnik" of the Serbian Learning Society and the Serbian Technical Gazette, as well as two textbooks:
"Perspective", in 1871, 32 pages and 5 tabs with drawings.

"Methodology of Descriptive Geometry" in 1899, 692 pages and 462 drawings.

Both books were printed in Belgrade at the State Printing Office of the Kingdom of Serbia.

His last scientific work "A new geometric theory of the normal stress of a straight beam" was published in 1901 as a volume of 81 pages with 8 tabs.

Professor Milan Bozic [4] mentions him as the author of the first scientific work in the field of mathematics in Serbia, but without data on the work itself. It is possible that this refers to his last work, because searching the Serbian bibliographic system COBISS, gives no other results. He was a regular member of the Serbian Learning Society and the Committee for the Spread of Science and Literature [5].

\section{CONCEPT OF METHODOLOGY OF DESCRIP- TIVE GEOMETRY}

The most important contribution of Dimitrije Stojanovic to Serbian literature in the field of descriptive and projective geometry is undoubtedly the "Methodology of Descriptive Geometry". The work on the book began in 1874, and ended in 1899, that is, after 25 years. The book has 692 pages of the text and 462 drawings, which were additionally printed at the end of the book.

On the front page, along with his name, it says that it was written after he retired from teaching at the Higher School. In the book's preface, the author exposes his desire to upgrade the descriptive geometry in the Higher School, where he was a professor for 12 years, to a higher level and to pay special attention to central projection. We will outline his introductory section on the importance of central projection:

"Central projection is a general method of projection, and if one would adopt the view that every scientific action should start from the general, and only afterwards to observe special cases, then the descriptive geometry method should start with central projection, as it was done by professor Fidler before me. " [6]

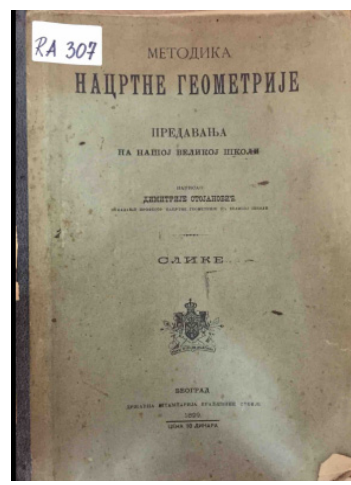

Figure 2. Book cover

In the initial chapter "Access," Dimitrije Stojanovic lists all mathematicians who laid out descriptive geometry as a science - Gaspard Monge, Hachette, Desargues, Poncelet, but his approach is closest to Fiedler's, especially in projective geometry. It is interesting that he had not mentioned any of Serbian authors, not even Emilijan Josimovic, who wrote the first textbook and 
with whom he certainly had joint contacts in the Technical Society. In "Access", he emphasizes the importance of terminology and outlines its significance for the technical profession.

The chapters in this comprehensive book are:

1. Orthogonal projection with axonometrics and quoted projection

2. Central projection

3. The theory of projective forms

4. Geometric theory of conic section

\section{Central collineation in space}

The significant influence of Otto Wilhelm Fiedler [7] (1832-1912) on the creation of this book is certainly there, so we will briefly mention main elements of his work. As a professor of mathematics Fielder worked in Freiberg and Chemnitz, as well as at the Technical University of Prague and Polytechnics in Zurich. He defended his doctoral dissertation "Die Zentralprojektion als geometrische Wissenschaft" (Central projection as geometric science) in Leipzig. Around 1870, several German authors expressed the need to synthesize descriptive and projective geometry, and this was later considered to be exclusively the German approach, which cannot be considered accurate, since there were similar ideas in Italy, in particular Luigi Cremona (1830 -1903). The entire process of synthesizing descriptive and projective geometry in Fiedler's eyes was an important task in order to improve the descriptive geometry and its technical applying.

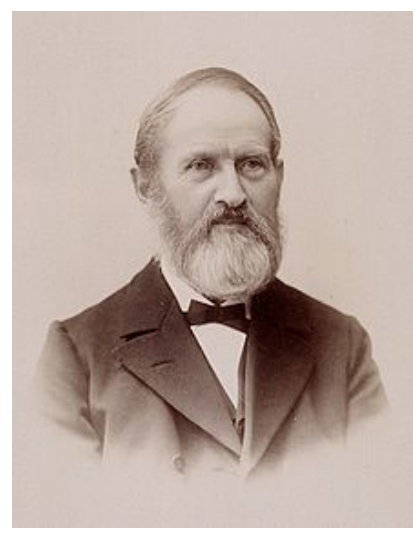

Figure 3. Oto Vilhelm Fiedler

In his paper, presented at the Academy of Sciences in Vienna in 1867, titled "The methodology of descriptive geometry as an introduction to the geometry of position" he works on the detailed elaboration of these ideas, which will be presented later in his books. We assume that Dimitrije Stojanovic, a Viennese student, was already familiar with Fidler's ideas during his studies, which is why he used the same title for his main work.

\section{SHORT BOOK REVIEW}

\subsection{Orthogonal projecting with axonometrics and quoted projection}

We saw in the foreword that this work should start with central projection but to make it simplier, Stojanovic decides to start with orthogonal projection. At the very beginning of the book in the section of the Point Fortress, the author explains the position of the projection planes, which he calls the drawing plane, defines their position as well as the position of the axis. He separates the space on octants which he calls space. For the science itself - descriptive geometry, he states:

"And indeed, it is a rare science in which the power of presentation and expression is required as it is in the descriptive geometry, but it is also the best tool for studying geometric forms, as well as a good opportunity for sharpening the mind and the righteousness of thoughts." [6] He pays special attention to the rules of drawing in the chapter called Drawing Norms, from the type and thickness of the line to the softness of the pen and the type of the feather.

In the chapter on affinity, the projection is explained in a downward position and with a connection towards other projections, and it is called "laying and lifting". Through the following drawings we will give an overview of the most important parts of the book in order to have a partial insight into this grand work. We consider that those are characteristic examples and, in particular, we emphasize that they are explained in details in the extensive textual part of the book.

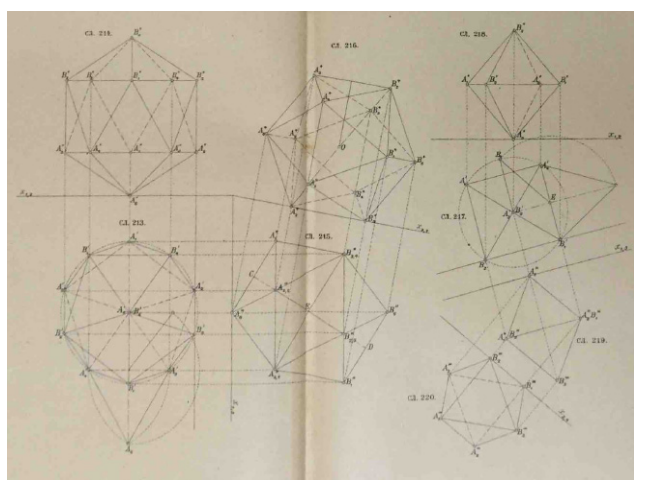

Figure 4. Platonic solids - Icosahedron, Octahedron, transformation

In the section on Platonic solids, he analyzes the Golden Ratio and its relation with the construction of a regular pentagon. For each figure - tetrahedron, cube, octahedron, icosahedron and pentagonal dodecahedron, the principles of their construction, as well as the relations among their edges and diagonals, are given. Much interest is shown in the research of crystallographic forms. Examples of rhombic dodecahedron and pyramidal hexahedron, are described with a thorough explanation of their origin and the relationship of particular dimensions. He sees the transformation as a way to solve and overcome technical difficulties and does not agree with French scientists Théodore Olivier (17931853) and Henri Édouard Tresca (1814-1885), who consider transformations as a special method in descriptive geometry and which exclude other methods. Stojanovic [6] considers that view as one-sided and aggravating in many situations as well as impoverishment of a kind, which abolishes other constructive procedures.

He explains the planar intersection of the pyramids and the prisms from the plane as the most common transformation, and drawing their networks as "dismantling". Only one example of figure intersection was 
made. The intersection of the two pyramids is explained extensively, but the drawing itself is quite vague. The principle of intersection of prisms is men-tioned, while there are no indications of the intersection of the curved solids.

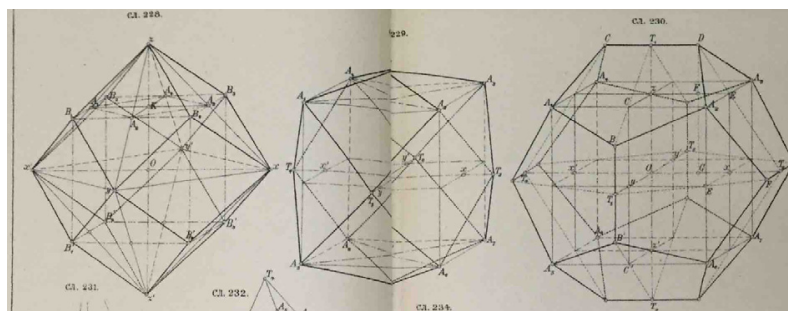

Figure 5. Crystallographic forms - rhombic dodecahedron, pentagonal dodecahedron
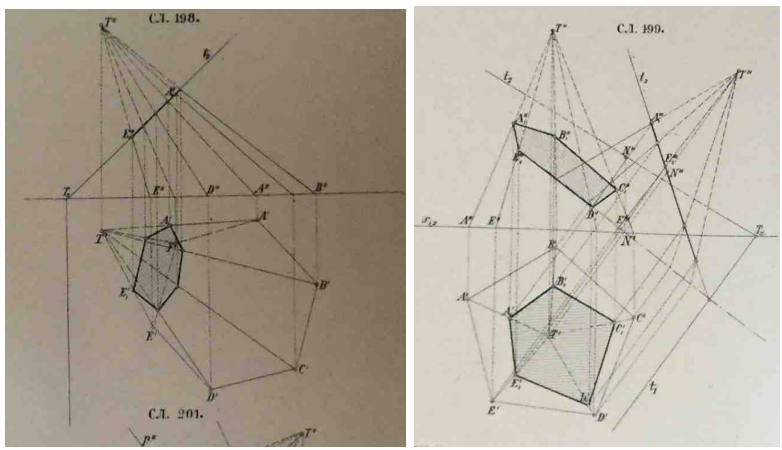

Figure 6. Planar intersection of pyramids

He gave a detailed analysis of roof solvings, explaining the cross-sectional views, using archaic terms for "valleys" and "ridges". He also explains the construction of roof racks, as well as cases of adjacent objects, according to which water from the roof should not be routed.

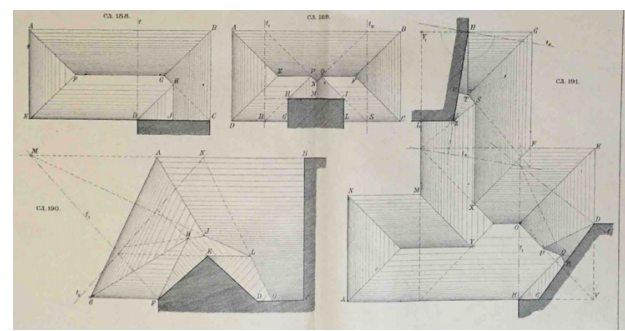

Figure 9. Roof solving

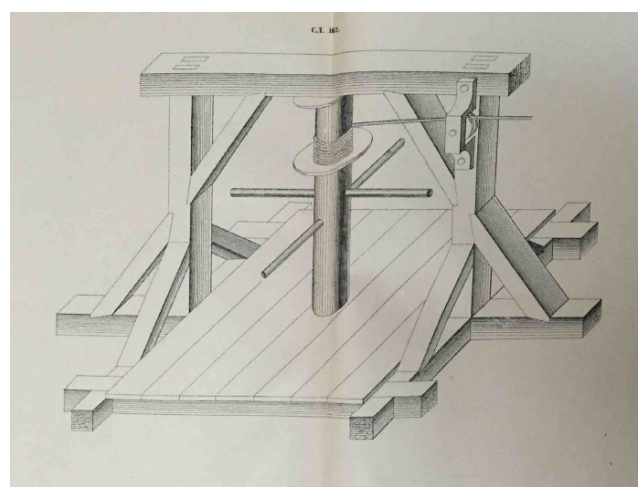

Figure 10. "Cavalier perspective"

Explaining the axonometric presentations, through the methods of setting the axis and plane, he finds the theoretical basis in the work of the contemporary Oscar Schlömilch (1823-1901), in the Schlemilh theorem of the construction of axonometric axes. He also presents interesting examples of the "Cavalier perspective" (a special type of parallel projection at $45^{\circ}$ angle in which there is no shortening).

\subsection{Central projection}

In many sciences, it is difficult to set the boundary between theoretical and practical work, because their pervasion contributes to the very development of science. What is the purpose of constructive central projection operations? Are they conducted due to practical problems or do they have a theoretical significance? Is the theoretical basis just a prerequisite for practical needs? Dimitrije Stojanović certainly argues that the theoretical basis is crucial for the exploration of geometric relations, which we conclude from the part of the book on central projectiing, which deals with the relations of a point, line and plane, as well as dealing with transformations and their applications, construc-tions, and the smallest part of this chapter is dedicated perspective and its application. A part about perspective pictures is extremely poor, illustrated by a unpretentious example.

In this relatively short chapter (about 50 pages), he explains the basic concepts of central projection, and the terms he uses can be considered contemporary because they are still used today in the literature on central projection - vanishing point, image plane, vanishing line , distance, distance circle ...

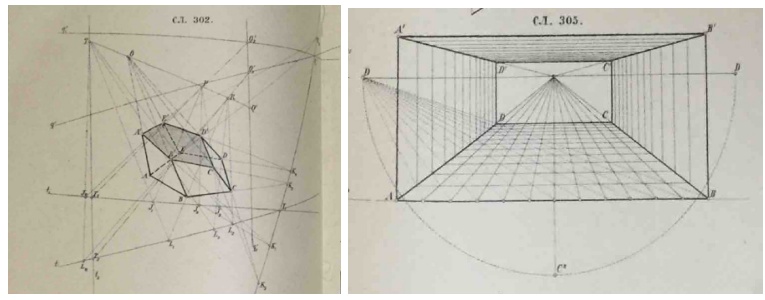

Figure 11. Planar intersection of the pyramid in the central projection and perspective picture

\subsection{The theory of projective forms}

The biggest part of the book is devoted to Projective geometry. The theory of projective forms, Stojanovic explains by insisting on a systematic study of projective forms. As a historical source of projective geometry, he lists the works of Girard Desargues (1591-1661), Gaspard Monge (1746-1818) and Jean-Victor Ponce-let (1788-1867). He gives interesting information like the one about General Ponsele, who was engaged in scientific work as a Russian prisoner in Saratov. He published it under the title Traité des propriétés projectives des figures (1822). He also notes Michel Floréal Chasles (17931880) as prominent mathematician who gave analytical character to projective geometry.

He considers projective geometry a fully-developed science, which originated from central projection, but has its own path and development. The laws applied between basic concepts in projective geometry, as well as their relations, he calls projective means or projectivity. He uses terminology similar to modern endless points, endless lines, networks, projective forms 
of first and second order, arrays, cross-ratio, harmonic points...

Desargues's theorem has exceptional significance in projective geometry, which refers to the perspective of triangles in relation to the axis. He was a French engineer, who first laid the foundations of projective geometry in the 17th century, which, after almost two centuries, evolved into a special geometric discipline. Stojanovic explains this theorem in great detail, as well as its reverse version, (called "reciprocal theorem") and mentions the work of Karl Georg von Staudt (17981867), to whom these theorems are the starting points for his work on projective geometry.

In the section on "Strings and strands" in a perspective position, he refers to the work of the Swiss mathematician Jakob Steiner (1796-1863), one of the founders of synthetic geometry.

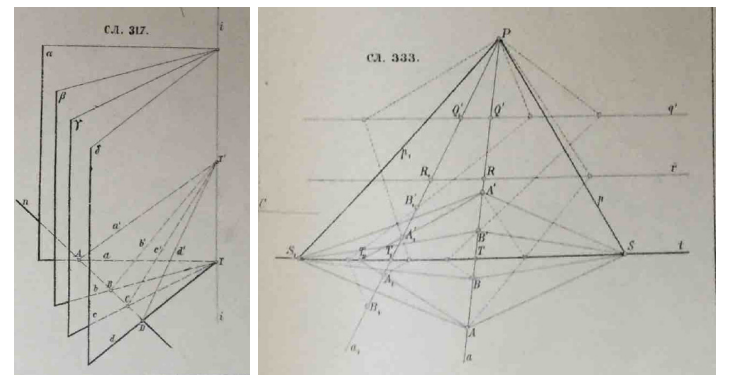

Figure 12. Examples of tasks from projective geometry

\subsection{Geometric theory of convex trains}

In this chapter, the archaic term "train" is used, representing a line in the general sense. Emilijan Josimovic, in the first university textbook [8], uses these terms as line trains (real) and curve trains (curves). Stojanović explains their development in two forms, such as conic cross sections (convex trains) and from the point of view of projective geometry, as central projections of the circle, citing Desargue and Pascal as the establishers of this method.

He concludes that convex trains are curves of the second order, and then gives the definition of each of them. We will take hyperbole as an example - "If the original circle cuts the non-inverse axis of two points, then the projected rays of these cut points are parallel to the image plane and intersect in its infinite points. It follows that the shape of the circle, as a convex train, has two infinitely distant points and is called hyperbole [6]." A hyperbole tangent, which cuts asymptotes, is constructed using the Pascal theorem. Through further analysis, he uses Brianchon's theorem on the properties of the inscribed and described hexagons of conical cross sections.

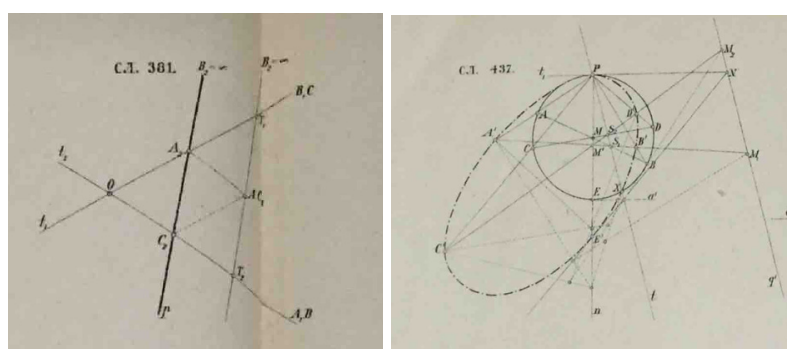

Figure 13. Pascals theorem, determening the center of the curve at the point of the elipse
In this chapter, he describes focus points, relations of the center and the diameter of curves, as well as the determination of the center of the curve at a given point of the curve. Special attention is devoted to the construction of curves with mandatory analytical evidence.

\subsection{Central collineation in space}

The last chapter determines the collinear systems and their significance in the descriptive geometry and perspective. The very concept of "relief" Dimitrije Stojanovic defines as "All points, lines, plane and other forms in system $\mathrm{S}$, in the following text - "original", and their coupled lines, planes and other forms in system S1 I will be calling relief [6]." So, he does not imply relief in geomorphological terms, but the concept of "relief perspective" relates to the linear perspective in central projection. As its practical usage, he mentions theater scenery and shallow reliefs in sculpturing which rise slightly above the surface. In this chapter, he wanted to bring the concept of projective geometry closer to the artistic understanding of the illusion of spatial depth.
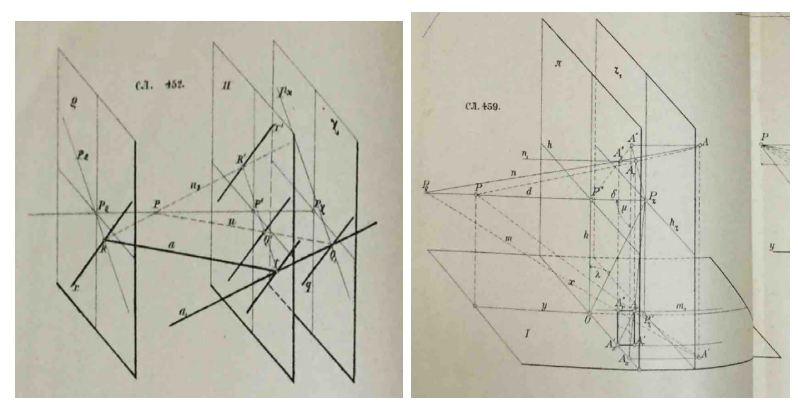

Figure 14. Plane systems

\section{CONCLUSION}

Dimitrije Stojanovic's, "Methodology of Descriptive Gemetry" was such comprehensive work that though it was written at the end of 19th century it exceedes many modern textbooks in its scope. The literature used by the author is, we can freely say, the most current literature of that time, in the field of projective geometry. Following the work of all European mathe-maticians Fiedler, Monge, Desargues, Pascal, Hasset, Poncelet and others, Stojanovic shows that he is fully aware of all published works in this field. At this point, we must ask ourselves, why is he forgotten as an author in Serbia. Of course, the time distance of over one century is certainly one of the factors, but the book was almost forgotten relatively quickly and we think we know why. Some of the reasons are:

- The title of the book (inspired by Findler's work) does not include temporary researchers for projective geometry, but only on descriptive geometry.

- He wrote the book after leaving Higher School and didn't have opportunity to receive feedback for it, that is, how students understood it.

- We must state that Emilijan Josimovic's book, written in archaic language, 25 years before Findler's, is much more understandable, and the drawings are much more readable. 
- At the beginning of the 20th century, with the creation of Belgrade University, the works of new generation of mathematicians appeared.

Dimitrije Stojanovic, honorable Minister of Construction and Finance, an engineer responsible for the development of the Serbian Railways, should certainly be remembered for the book in which he introduced the most up-to-date knowledge of geometry of those times.

\section{REFERENCES}

[1] Avramović S. Marković Z. (2008), Univerzitetsko obrazovanje u Evropi i Velika škola 1808. godine, Od Velike škole i Liceja do danas, Beograd

[2] Živanović Ž. (1924), Politička istorija Srbije u drugoj polovini 19v. 1889-1897, Beograd

[3] Jelenković N. (2010), Uloga matematike u vojnom obrazovanju, Vojno delo, Beograd

[4] Božić, M. (2002), Pregled istorije i filozofije matematike, Beograd

[5] Gavrilović B. (1906) Nekrolozi: Dimitrije Stojanović, Godišnjak, broj XIX, Srpska kraljevska akademija, Beograd, , str. 380-382

[6] Stojanović, D, (1899), Metodika nacrtne geometrije, Beograd

[7] Volkert K., Otto Wilhelm Fiedler and the Synthesis of projective and descriptive geometry,
Descriptive Geometry: The Spread of a Polytechnic Art ( 2018)

[8] Josimović, E., Osnovi nacrtne geometrije i perspektive, Beograd (1874)

[9] Jevtić-Novaković K., Đalović S., Mićović M. (2015), Oglednice profesora Emilijana, časopis Izgradnja 69

\section{НАЦРТНА ГЕОМЕТРИЈА У СРБИЈИ КРАЈЕМ 19. ВЕКА, КРОЗ ПРИКАЗ ДЕЛА ДИМИТРИЈА СТОЈАНОВИЋА}

\section{К. Јевтић-Новаковић, О. Тимченко, М. Дивац}

У овом раду ћемо приказати рану историју наставе нацртне геометрије у Србији, анализирајући књигу "Методологија нацртне геометрије" Димитрија Стојановића. Рад на књизи започео је 1874. године, а завршио је 1899. године, дакле пуних 25. година. Књига има 692 стране текста и 462 цртежа, који су посебно штампани на крају књиге. Тако свеобухватан уџбеник, који је написан крајем 19. века, по обиму превазилази многе савремене уџбенике. Стојановићева "Методологија нацртне геометрије" је први покушај синтезе нацртне и пројективне геометрије. 